\title{
UPAYA MENINGKATKAN HASIL BELAJAR DAN KEAKTIFAN BELAJAR MATEMATIKA MENGGUNAKAN METODE GAMBAR
}

\section{EFFORT TO IMPROVE THE LEARNING RESULT OF STUDY MATHEMATICS AND LIVELINESS BY USING LEARNING METHOD OF PICTURE}

\author{
S Susantia, LO Amrili1 ${ }^{1}$ dan A Kurniawati ${ }^{1}$ \\ ${ }^{1}$ Program Studi Pendidikan Guru Sekolah Dasar, Fakultas Keguruan dan Ilmu Pendidikan, \\ Universitas Djuanda Bogor, Jl. Tol Ciawi No. 1 Kotak Pos 35 Ciawi Bogor 16720 \\ a Korespondensi: Sri Susanti, Email: bundadevindra@gmailcom \\ (Diterima: 28-12-2016; Ditelaah: 28-12-2016; Disetujui: 06-03-2017)
}

\begin{abstract}
Classroom action research aims to improve learning outcomes and activeness of students in the basic concepts of arithmetic operations mixture of multiplication and division by using picture and picture method. This study is conducted by two cycles using Kemmis cycle models and Mc Taggart. In this model, there are four steps which must be done for each cycle, they are plan, act, observe, and reflect. The subject of this study are all IV grade students of Cibunian state elementary school, Pamijahan sub district Bogor regency. It consists of 30 students. The data are collected by using observation, achievement test, and documentation. The results of the research shows the average grade of mathematics by using picture and picture on the first cycle scored are $(76,33)$ the percentage of students who pass the test are $86,67 \%$, while the second cycle obtain the average grade (82) the percentage of completing the test are $93,33 \%$. for so the results of students' activity are increase in the participation of the students at $63,33 \%$ in the first cycle, it increases in the second cycle at $86,67 \%$, thus achieving the success criteria is expected in the second cycle. Thus, the results of studying mathematics and students' learning activeness of Cibunian state elementary school, Pamijahan sub district Bogor regency can be improved by applying picture and picture learning method.
\end{abstract}

Keywords: learning outcomes, liveliness, mathematics, methods picture and picture.

\begin{abstract}
ABSTRAK
Penelitian tindakan kelas ini bertujuan untuk meningkatkan hasil belajar dan keaktifan belajar siswa pada materi operasi hitung campuran perkalian dan pembagian menggunakan metode picture and picture. Penelitian ini dilakukan sebanyak dua siklus dengan menggunakan model siklus Kemmis dan Mc Taggart. Dalam model ini terdapat empat tahapan yang harus dilakukan pada tiap siklusnya yaitu plan (perencanaan), act (pemberian tindakan), observe (pengamatan), dan reflect (refleksi). Subjek dalam penelitian ini yaitu seluruh siswa kelas empat Sekolah Dasar Negeri Cibunian 01 Kecamatan Pamijahan Kabupaten Bogor yang terdiri dari 30 siswa. Data diperoleh dari observasi langsung selama pembelajaran, tes hasil belajar, dan dokumentasi. Hasil penelitian ini menunjukan nilai ratarata hasil belajar matematika pada siklus 1 memperoleh nilai $(76,33)$ dengan persentase siswa yang tuntas sebesar $86,67 \%$, sedangkan siklus 2 memperoleh nilai rata-rata (82) dengan persentase siswa yang tuntas sebesar 93,33\%. Begitu pula dengan hasil keaktifan belajar siswa menunjukan adanya peningkatan pada keaktifan siswa dengan persentase sebesar $63,33 \%$ pada siklus 1, meningkat pada siklus 2 dengan persentase $86,67 \%$, sehingga dapat mencapai kriteria keberhasilan yang diharapkan pada siklus 2. Dengan demikian, hasil
\end{abstract}


belajar matematika dan keaktifan belajar siswa SDN Cibunian 01 Kecamatan Pamijahan Kabupaten Bogor dapat ditingkatkan dengan menerapkan metode pembelajaran yang disesuaikan.

Kata kunci: hasil belajar, keaktifan, matematika, metode picture and picture.

Susanti S, LO Amril, dan A Kurniawati. 2017. Upaya meningkatkan hasil belajar dan keaktifan belajar matematika menggunakan metode gambar. Didaktika Tauhidi Jurnal Pendidikan Guru Sekolah Dasar 4(1): 31-43.

\section{PENDAHULUAN}

Hilgart and Bower (Baharuddin dan Wahyuni 2007) menyatakan bahwa belajar (to Learn) memiliki arti, to gain knowledge, comprehention, or mastery of trough experience or study to fix in the mind or memory memorize to acquire trough experience to become in forme of to find out. Hal ini berarti bahwa belajar memiliki pengertian memperoleh pengetahuan atau menguasai pengetahuan melalui pengalaman, mengingat, menguasai pengalaman, mendapatkan informasi atau menemukan.

Belajar yang berhasil harus melalui berbagai macam aktivitas, baik aktivitas fisik maupun psikis. Saat siswa aktif dari aspek jasmani, maka dengan sendirinya siswa juga aktif dari aspek jiwanya dan begitu juga sebaliknya. Keaktifan siswa dalam kegiatan belajar tidak lain adalah untuk mengkonstruksi pengetahuan mereka sendiri. Mereka dapat aktif membangun pemahaman atas persoalan atau segala sesuatu yang mereka hadapi dalam kegiatan pembelajaran.

Dalam proses pembelajaran matematika, tidak jarang ditemui siswa yang kurang terlibat dan lebih banyak bermain sendiri daripada mendengarkan penjelasan guru. Hal ini berakibat pada situasi belajar tampak kurang mencerminkan suasana aktif, kreatif, dan menyenangkan. Bila iklim pembelajaran seperti ini terus menerus berlangsung, maka untuk meningkatkan keterkaitan siswa terhadap materi ajar matematika tidak akan tercapai, bisa saja hasilnya semakin menjadi sebaliknya, yakni siswa akan kurang tertarik pada pelajaran matematika karena dianggap pelajaran yang membosankan.

Permasalahan tersebut juga terjadi di kelas IV SDN Cibunian 01 Kecamatan Pamijahan Kabupaten Bogor. Berdasarkan hasil observasi yang dilakukan oleh peneliti pada tanggal 29 Oktober 2016 tampak siswa kurang menyukai atau tertarik dengan pembelajaran matematika. Terlihat dari kurang antusiasnya siswa dalam mengikuti pembelajaran. Siswa lebih banyak mengobrol dan tidak memperhatikan penjelasan guru.

Berdasarkan data nilai UTS tahun pelajaran 2016/2017 pada materi operasi hitung perkalian dan pembagian, dari 30 siswa hanya 12 siswa (40\%) yang memperoleh nilai di atas standar ketuntasan minimal 70 sisanya masih di bawah standar yang ditetapkan. Hasil observasi tersebut diduga yang menjadi sebab hasil belajar matematika siswa kelas IV SDN Cibunian 01 Kecamatan Pamijahan Bogor masih tergolong rendah.

Banyak faktor yang menyebabkan hasil belajar matematika dan keaktifan belajar matematika siswa SDN Cibunian 01 masih tergolong rendah. Salah satu faktornya ialah faktor internal dan faktor eksternal. Faktor internal siswa antara lain berupa motivasi 
siswa, kesiapan siswa, keadaan fisik siswa, dan kecerdasan siswa. Sedangkan faktor eksternal antara lain guru, perhatian orang tua, sarana dan prasarana, kurikulum, buku penunjang, materi pokok, dan lingkungan belajar. Faktor internal (siswa) tersebut timbul dikarenakan guru belum banyak menerapkan metode pembelajaran yang bervariasi dan belum sepenuhnya melibatkan siswa secara aktif dalam proses pembelajaran. Siswa hanya diajarkan cara menyelesaikan persoalan matematika yang cenderung tidak mudah dipahami oleh siswa. Untuk itu, diperlukan metode dan media yang sesuai dan menarik dalam pembelajaran matematika khususnya pada materi operasi hitung perkalian dan pembagian.

Berdasarkan latar belakang tersebut peneliti termotivasi untuk mengoptimalkan pembelajaran matematika pada peserta didik di Sekolah Dasar tersebut. Salah satu upaya yang diduga dapat memecahkan masalah tersebut adalah dengan penerapan metode pembelajaran picture and picture sebagai salah satu metode yang diharapkan dapat lebih melibatkan siswa secara aktif dalam pembelajaran matematika. Metode pembelajaran picture and picture ialah metode pembelajaran yang lebih mengandalkan gambar sebagai media dalam proses pembelajaran.

\section{MATERI DAN METODE}

\section{Materi}

Hasil belajar adalah perubahan yang mengakibatkan manusia berubah dalam sikap dan tingkah lakunya (Purwanto 2011). Belajar dilakukan untuk mengusahakan adanya perubahan perilaku untuk pada individu yang belajar. Perubahan perilaku itu merupakan perolehan yang menjadi hasil belajar. Perubahan-perubahan yang terjadi pada diri siswa yang dimaksud ialah perubahan yang menyangkut aspek kognitif, afektif, dan psikomotorik sebagai hasil dari kegiatan belajar.

Pendapat lain menyatakan bahwa hasil belajar dapat diartikan sebagai tingkat keberhasilan siswa dalam mempelajari materi pelajaran di sekolah yang dinyatakan dalam skor yang diperoleh dari hasil tes mengenai sejumlah materi pelajaran tertentu.

Hasil belajar merupakan realisasi tercapainya tujuan pendidikan, sehingga hasil belajar yang diukur sangat tergantung kepada tujuan pendidikannya. Hasil belajar perlu di evaluasi, evaluasi dimaksudkan sebagai cermin untuk melihat kembali apakah tujuan yang ditetapkan telah tercapai dan apakah proses belajar mengajar telah berlangsung efektif untuk memperoleh hasil belajar.

Hal ini sesuai dengan pendapat Sunal dan Haas (1993), evaluasi merupakan proses penggunaan informasi untuk membuat pertimbangan seberapa efektif suatu program telah memenuhi kebutuhan siswa. Selain itu, dengan dilakukannya evaluasi atau penilaian dapat dijadikan feedback atau tindak lanjut, atau bahkan cara untuk mengukur tingkat penguasaan siswa. Pendapat ini didukung oleh Susanto (2013) bahwa kemajuan prestasi belajar siswa tidak saja diukur dari tingkat penguasaan ilmu pengetahuan, tetapi juga sikap dan keterampilan. Dengan demikian, penilaian hasil belajar siswa mencangkup segala hal yang dipelajari di sekolah, baik itu menyangkut pengetahuan, sikap, dan keterampilan, yang berkaitan dengan mata pelajaran yang diberikan kepada siswa.

Metode pembelajaran adalah suatu cara yang digunakan untuk mengimplementasikan rencana yang sudah 
disusun dalam bentuk kegiatan nyata dan praktis demi mencapai tujuan pembelajaran. Salah satu tujuan pembelajaran ialah hasil belajar yang lebih baik dari sebelumnya. Beberapa contoh metode pembelajaran yang umum digunakan ialah seperti metode ceramah, metode diskusi, metode simulasi, metode demonstrasi, metode eksperimen, dan lainlain.

Metode pembelajaran picture and picture merupakan salah satu metode pembelajaran dengan menggunakan gambar dan dipasangkan atau diurutkan menjadi urutan logis. Prinsip dasar dalam metode picture and picture ialah setiap anggota kelompok (siswa), bertanggung jawab atas segala sesuatu yang dikerjakan dalam kelompoknya, mengetahui bahwa semua anggota kelompok memiliki tujuan yang sama, membagi tugas dan tanggung jawab yang sama diantara anggota kelompoknya, berbagi kepemimpinan dan membutuhkan keterampilan untuk belajar bersama selama proses belajarnya, serta akan diminta mempertanggung jawabkan secara individual materi yang ditangani dalam kelompok kooperatif.

Pembelajaran ini memiliki ciri aktif, inovatif, kreatif, dan menyenangkan. Metode pembelajaran ini mengandalkan gambar sebagai media dalam proses pembelajaran. Gambar-gambar ini menjadi faktor utama dalam proses pembelajaran. Penerapan metode pembelajaran cooperatif picture and picture pada mata pelajaran matematika, dimana seorang guru dapat menyampaikan kompetensi yang ingin dicapainya, menyajikan materi serta gambar-gambar yang sesuai dengan materi yang akan disampaikan.

Pembelajaran menggunakan metode picture and picture dapat menuntut siswa untuk berperan aktif dalam pembelajaran tersebut, siswa dapat mengurutkan gambar menjadi urutan yang benar. Kemudian guru menanyakan alasan dan urutan gambar tersebut guru mulai untuk menanamkan materi yang sesuai dengan kompetensi yang ingin dicapai, sehingga siswa dengan mudah memahami konsep pembelajaran.

\section{Metode}

\section{Metode Penelitian}

Jenis penelitian ini adalah penelitian tindakan kelas (Classroom Action Research) yang bertujuan untuk meningkatkan hasil belajar matematika dan keaktifan siswa pada materi pembelajaran operasi hitung perkalian dan pembagian. Penelitian ini dilaksanakan di SD Negeri Cibunian 01 Bogor yang beralamat di Kp. Cibunian RT. 001/011 Desa Cibunian Kecamatan Pamijahan Kabupaten Bogor pada bulan Oktober sampai November 2016.

Adapun subjek dalam penelitian ini adalah siswa kelas IV Sekolah Dasar Negeri Cibunian 01 Kecamatan Pamijahan Kabupaten Bogor dengan jumlah siswa sebanyak 30 orang yang terdiri dari 14 siswa laki-laki dan 16 siswi perempuan.

Salah satu manfaat adanya penelitian tindakan kelas antara lain guru dapat meneliti sendiri terhadap praktik pembelajaran yang dilakukannya di kelas dan guru juga dapat melakukan penelitian terhadap siswa jika dilihat dari aspek interaksinya dalam proses pembelajaran.

Selain itu, dengan melakukan penelitian tindakan kelas, guru juga dapat memperbaiki praktik pembelajaran yang dilakukan menjadi lebih berkualitas dan lebih efektif. Metode penelitian tindakan kelas ini dilakukan pada pembelajaran matematika dengan menggunakan metode picture and picture guna meningkatkan hasil belajar dan keaktifan belajar siswa dengan 
pokok bahasan operasi hitung campuran (perkalian dan pembagian).

Dalam matematika, maksud operasi pada pengerjaan operasi hitung matematika diartikan sebagai pengerjaan hitung. Negoro menyatakan bahwa operasi hitung atau pengerjaan hitung pada dasarnya meliputi empat pengerjaan dasar yaitu penjumlahan, pengurangan, perkalian, dan pembagian (Esti 2015).

Materi perkalian, pembagian, dan operasi hitung campuran adalah materi untuk siswa kelas empat sekolah dasar semester pertama. Dalam pembelajarannya siswa diharapkan mampu menguasai bagaimana proses perkalian dan pembagian yang baik dan benar.

Desain penelitian tindakan kelas dalam penelitian ini menggunakan model Kemmis \& Mc Taggart karena sederhana dan mudah dipahami. Rancangan Kemmis \& Mc Taggart dapat mencakup sejumlah siklus, masingmasing terdiri dari tahap-tahap, yaitu diantaranya:

1. perencanaan (planning);

2. pelaksanaan (acting);

3. pengamatan (observing);

4. refleksi (reflecting).

Tahapan-tahapan ini berlangsung secara berulang-ulang, sampai tujuan penelitian tercapai. Apabila dituangkan dalam bentuk gambar, rancangan Kemmis \& Mc Taggart akan tampak seperti Gambar 1.

Refleksi awal adalah kegiatan mengulang atau memberikan tes untuk mengetahui dan mendapatkan data awal sebelum penelitian. Perencanaan tindakan dimulai dari identifikasi masalah yang akan diteliti. Setelah diuji kelayakan masalah yang akan diteliti, kemudian direncanakan tindakan selanjutnya. Pelaksanaan tindakan yaitu kegiatan melaksanakan apa yang sudah direncanakan oleh peneliti.

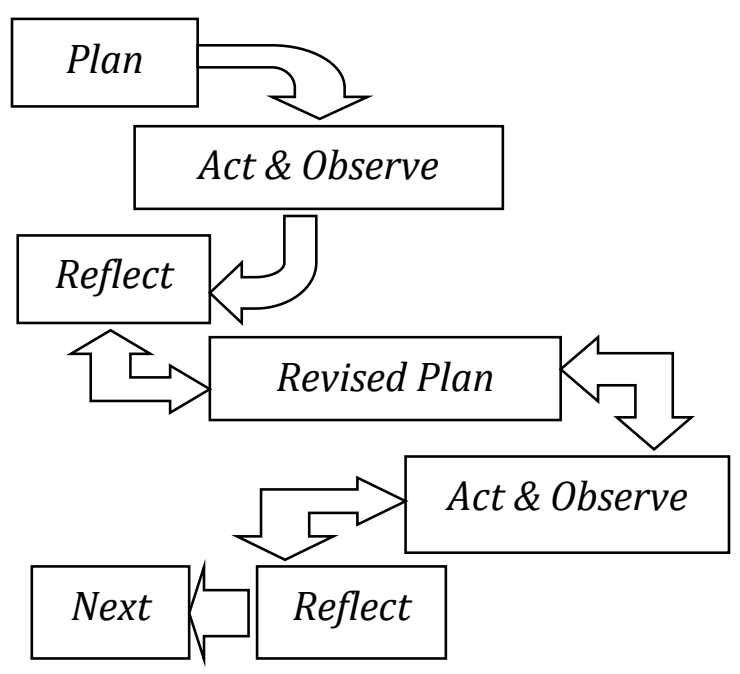

Gambar 1 Model Kemmis \& Mc Taggart

Adapun observasi adalah pengamatan selama berlangsungnya kegiatan pembelajaran. Evaluasi atau refleksi adalah kegiatan mengulas atau mengulang materi yang baru saja dipelajari. Berdasarkan hasil refleksi, guru menyimpulkan tindakan yang dilakukan dapat mencapai keberhasilan dari seluruh indikator yang sudah ditentukan ataukah belum.

Prosedur pertama dari tindakan penelitian yang peneliti lakukan adalah melaksanakan pra siklus. Pra siklus dilaksanakan dengan tujuan untuk mengetahui kemampuan awal siswa sebelum tindakan penelitian. Hasil tes pra siklus menunjukkan bahwa dari jumlah peserta didik 30 siswa, rata-rata yang diperoleh sebesar 69,87 hampir mendekati Kriteria Ketuntasan Minimal (KKM) 70. Berdasarkan hal tersebut penelitian selanjutnya menyusun perencanaan siklus 1.

Pada tahap perencanaan siklus 1 peneliti merumuskan hal-hal dan langkah-langkah yang diperlukan dalam proses pembelajaran dengan menganalisis kebutuhan yang diperlukan serta menyusun rencana tindakan yang akan dilakukan. Hal Ini dilakukan setelah peneliti menemukan 
kelemahan-kelemahan yang ditemui pada pertemuan sebelumnya (tes pra siklus).

Adapun hal-hal yang dipersiapkan antara lain: (1) membuat skenario pembelajaran yang dituangkan dalam format Rencana Pelaksanaan Pembelajaran (RPP); (2) membuat skenario pembelajaran yang dituangkan dalam format silabus; (3) menyiapkan alat dan bahan yang diperlukan dalam pelaksanaan pembelajaran untuk pelaksanaan pembelajaran; dan berkoordinasi dengan teman sejawat untuk kelancaran tindakan refleksi dan perbaikan selanjutnya.

Pada tahap pelaksanaan siklus 1, langkah-langkah pembelajarannya sebagai berikut, guru pada tahap pelaksanaan siklus 1: (1) melakukan apersepsi dengan cara bertanya jawab seputar keadaan siswa lalu dikaitkan dengan materi; menyampaikan judul materi yang akan dipelajari; (3) membentuk kelompok (menyesuaikan dengan kelompok belajar yang sudah terbentuk); dan (4) memotivasi siswa dengan menunjukan gambar-gambar (picture and picture) yang menarik tentang operasi hitung campuran (perkalian dan pembagian) dan menyampaikan tentang pembelajaran yang akan dilaksanakan.

Kegiatan inti, siswa berperan dalam: (1) melakukan pembelajaran menggunakan media gambar secara berkelompok, dan sebagai acuan, setiap kelompok diberikan pegangan berupa materi yang akan dipelajari; (2) penyampaian hasil kerja kelompok, dan penentuan kelompok terbaik; dan (3) melakukan tanya jawab antara guru dengan siswa untuk meluruskan kesalahpahaman, memberikan penguatan dan penyimpulan.

Pada kegiatan penutup, secara bersamasama guru dan siswa menyimpulkan akhir kegiatan pembelajaran yang dilakukan. Selanjutnya siswa mengerjakan tes individual untuk mengukur pemahaman konsep, serta di akhir kegiatan guru memberikan tugas (PR).

Observasi dilakukan selama proses pembelajaran berlangsung. Dalam hal ini peneliti pun tak luput melakukan observasi terhadap aktifitas peserta didik dalam kegiatan pembelajaran untuk menilai keaktifan masing-masing peserta didik. Pada tahap refleksi, guru (peneliti) melakukan evaluasi tentang penilaian keaktifan proses belajar di kelas serta hasil belajar secara individu dan kelompok.

Hasil evaluasi dapat direfleksikan dalam bentuk rekomendasi untuk dilanjutkan ke siklus 2 dengan perbaikan pada RPP, silabus, indikator pada materi pembelajaran, LKS, instrumen penilaian, dan lain-lain. Namun pendekatan dan metode pembelajaran adalah tetap.

Perencanaan kegiatan pada siklus 2 dibuat dengan terlebih dahulu menganalisis kelemahan dan kelebihan pada perencanaan siklus 1. Rumusan perencanaan sebagian besar relatif sama dengan siklus 1 , hanya ada penambahan-penambahan yang didapat dari hasil observasi dan refleksi. Sedangkan pada tahap pelaksanaan siklus 2 langkahlangkah pembelajaran yang dilakukan tidak terlalu jauh dari skenario pembelajaran pada siklus 1 . Hanya ada perubahan dan perbaikan pada penggunaan alat dan bahan serta lebih mengoptimalkan pengamatan.

Hal ini dilakukan dengan jalan peneliti dibantu teman (guru) guna mengobservasi dan menilai pelaksanaan dan pembelajaran dengan menggunakan instrumen penilaian pelaksanaan pembelajaran yang sama dengan memperhatikan aspek/indikator yang direfleksikan oleh siklus 1 .

Selanjutnya observer melakukan observasi keaktifan siswa dengan menggunakan lembar observasi keaktifan 
siswa. Pada kegiatan refleksi pada siklus 2 tidaklah terlalu mendasar, karena sebagian besar tindakan perbaikan telah dianggap optimal dan berhasil.

\section{Instrumen Penelitian}

Adapun instrumen yang digunakan dalam penelitian ini bertujuan untuk memperoleh data tentang keaktifan pembelajaran siswa dan hasil belajar pada mata pelajaran matematika. Hal ini dilakukan dengan metode picture and picture dalam pembelajaran operasi hitung campuran (perkalian dan pembagian) di kelas IV Sekolah Dasar Negeri Cibunian 01 Kecamatan Pamijahan Kabupaten Bogor semester 1 tahun pelajaran 2016/2017. Adapun data dikumpulkan dengan instrumen berupa tes hasil belajar dan lembar pengamatan keaktifan siswa.

Soal instrumen hasil belajar terdiri dari sepuluh soal pilihan ganda dengan alternatif pilihan jawaban (a, b, c, d), sedangkan instrumen lembar observasi terdiri dari sepuluh pernyataan yang diisi oleh observer untuk mengamati keaktifan siswa selama kegiatan pembelajaran berlangsung dengan penerapan metode picture and picture. Teknik analisis data yang digunakan ialah statistik deskriptif dengan tahapan-tahapan antara lain: pengumpulan data, reduksi data, dan pemaparan data.

\section{Teknik Pengumpulan Data}

Pada tahap pengumpulan data, peneliti mengumpulkan data yang diperoleh dari hasil penelitian pelaksanaan pembelajaran di kelas, observasi keaktifan siswa, dan hasil belajar. Selanjutnya pada tahap reduksi, peneliti memilih dan memilah data yang relevan serta tidak relevan (data yang tidak relevan dibuang). Dilanjutkan pada tahap terakhir yakni pemaparan data, peneliti menyajikan data-data yang terseleksi dalam bentuk urutan jenis data dengan menghitung rata-rata dan persentase, serta melakukan analisis dan interpretasi data. Pada bagian akhir pengkategorian data yakni pengelompokkan data sesuai kategori dan menginterpretasikannya. Konversi nilai yang diperoleh dikategorikan seperti pada Tabel 1.

Penelitian tindakan kelas ini memberikan ketentuan bahwa jika dilakukan tindakan perbaikan keaktifan siswa yang berdampak positif pada hasil belajarnya, maka indikator keberhasilan dalam penelitian ini dapat dirumuskan sebagai berikut.

1. Indikator keberhasilan hasil belajar minimal $80 \%$ (peraturan KTSP di sekolah) dari jumlah siswa mencapai KKM 70.

2. Indikator keberhasilan keaktifan siswa dalam pembelajaran minimal 'Baik' secara kualitatif 60-80 dengan kategori B.

Tabel 1 Konversi nilai

\begin{tabular}{ccl}
\hline $\begin{array}{c}\text { Interval } \\
\text { Nilai }\end{array}$ & Kategori & \multicolumn{1}{c}{ Makna } \\
\hline $80-100$ & A & Sangat baik \\
$60-80$ & B & Baik \\
$40-60$ & C & Cukup \\
$20-40$ & D & Kurang baik \\
$0-20$ & E & Jelek/sangat \\
& & tidak baik. \\
\hline
\end{tabular}

\section{HASIL DAN PEMBAHASAN}

\section{Hasil}

Temuan penelitian dimulai pada pra siklus, kemudian dilanjutkan ke siklus 1 dan 2 hingga mencapai nilai ketuntasan hasil belajar dan keaktifan belajar siswa yang sesuai dengan tujuan penelitian. Penelitian dilaksanakan di Sekolah Dasar Negeri 
Cibunian 01, dimana sekolah ini berdiri sejak tahun 1952 dan berlokasi di Kecamatan Pamijahan Kabupaten Bogor pada tahun ajaran 2016/2017.

Kegiatan awal (pra siklus) dilaksanakan pada tanggal 3 Oktober 2016 dan pemberian tes awal pada tanggal 31 Oktober 2016. Subjek dalam penelitian ini adalah siswa kelas IV yang berjumlah 30 orang yang terdiri dari 16 siswa laki-laki dan 14 siswi perempuan. Penelitian ini dilakukan dalam rangka memperbaiki keaktifan belajar dan hasil belajar siswa pada mata pelajaran matematika khususnya materi operasi hitung perkalian dan pembagian dengan penerapan metode pembelajaran picture and picture. Adapun data hasil tes awal (pra siklus) yang dilaksanakan sebelum pemberian tindakan disajikan pada Tabel 2.

Tabel 2 Rekapitulasi nilai pra siklus

\begin{tabular}{lrr}
\hline Ketuntasan & Jumlah Siswa & Presentase \\
\hline Tuntas & 20 & $66,67 \%$ \\
Belum Tuntas & 10 & $33,33 \%$ \\
Jumlah & 30 & $100 \%$ \\
\hline
\end{tabular}

Adapun untuk mengetahui kemampuan awal siswa sebelum pelaksanaan tindakan maka diberikanlah tes kemampuan awal dimana hasil pelaksanaan tes kemampuan awal disajikan pada Tabel 3.

Tabel 3 Rekapitulasi nilai tes kemampuan awal

\begin{tabular}{lrr}
\hline Ketuntasan & Jumlah Siswa & Presentase \\
\hline Tuntas & 21 & $70,00 \%$ \\
Belum Tuntas & 9 & $30,00 \%$ \\
Jumlah & 30 & $100,00 \%$ \\
\hline
\end{tabular}

\section{Deskripsi Pembelajaran Siklus 1}

Sebelum pelaksanaan pembelajaran siklus 1, peneliti merumuskan hal-hal dan langkah-langkah yang diperlukan dalam proses pembelajaran dengan cara menganalisis kebutuhan yang diperlukan serta menyusun rencana tindakan yang akan dilakukan.

Adapun hal-hal yang dipersiapkan antara lain membuat skenario pembelajaran yang dituangkan dalam format Rencana Pelaksanaan Pembelajaran (RPP) dan membuat instrumen pengumpulan data yang diperlukan (diharapkan instrumen tersebut dapat mengukur dan menilai pembelajaran yang sejalan dengan tujuan penelitian. Selain itu peneliti juga menyiapkan alat dan bahan yang diperlukan dalam pelaksanaan pembelajaran, serta berkoordinasi dengan teman-teman sejawat untuk kelancaran tindakan refleksi dan perbaikan selanjutnya.

Pada tahap siklus 1, langkah-langkah pembelajaran yang dilakukan ialah sebagai berikut. Pada kegiatan awal, peneliti melakukan apersepsi dengan cara bertanyatanya seputar keadaan siswa lalu dikaitkan dengan materi yang akan dipelajari. Selanjutnya siswa membentuk kelompok belajar (menyesuaikan dengan kelompok belajar yang sudah terbentuk). Guru bertugas memotivasi siswa dengan menunjukkan kartu angka-angka atau gambar dan menyampaikan tentang pembelajaran menggunakan metode pictrure and picture.

Pada kegiatan inti, proses eksplorasi dilakukan dengan melakukan pembelajaran secara berkelompok, yaitu menghitung operasi hitung campuran perkalian dan pembagian yang telah dikemas dalam kartu angka atau gambar, dan sebagai acuan setiap kelompok diberikan pegangan berupa karton yang akan dikerjakan bersama-sama dengan kelompoknya yang akan dihitung lalu ditempelkan yang 
bertujuan supaya siswa dapat mengerjakan tugas dengan baik.

Dalam elaborasi, terjadi penyampaian hasil kerja kelompok dan penentuan kelompok terbaik. Selanjutnya tahap konfirmasi, yakni dengan melakukan tanya jawab antara guru dengan siswa untuk meluruskan kesalahpahaman, memberikan penguatan dan penyimpulan.

Pada kegiatan akhir pembelajaran, secara bersama-sama guru dan siswa menyimpulkan kegiatan yang telah dilakukan, dan secara individu siswa mengerjakan soal tes yang diberikan guna mengukur pemahaman konsep. Sebelum kegiatan pembelajaran ditutup, guru memberikan tugas (PR) yang dikerjakan secara mandiri di rumah.

Pada pelaksanaan pembelajaran siklus 1, pengumpulan data dilakukan selama dan setelah pembelajaran. Selama proses pembelajaran dilakukan pengumpulan data berupa observasi terhadap keaktifan siswa dengan mengisi lembar observasi yang telah dipersiapkan serta melakukan penilaian hasil belajar siswa.

Tahap refleksi dilakukan setelah menganalisis lembar observasi keaktifan siswa dan analisis hasil belajar siswa serta masukan-masukan dari teman sejawat yang dilibatkan sebelumnya. Selain itu peneliti juga merefleksikan sendiri temuan-temuan masalah saat proses pembelajaran. Hasil refleksi pada siklus 1 peneliti jadikan patokan untuk menyusun rencana perbaikan pada siklus 2 .

Pada Tabel 4 menunjukan bahwa dari 30 siswa terdapat 26 siswa $(86,67 \%)$ yang sudah mencapai Kriteria Ketuntasan Minimal (KKM) dalam belajar atau mencapai nilai minimal 70. Sementara itu, terdapat 4 siswa $(13,33 \%)$ yang memperoleh nilai di bawah KKM.
Tabel 4 Ketuntasan hasil belajar siklus I

\begin{tabular}{lrr}
\hline Ketuntasan & Jumlah Siswa & \multicolumn{1}{c}{$\%$} \\
\hline Tuntas & 26 & 86,67 \\
Belum Tuntas & 4 & 13,33 \\
Jumlah & 30 & 100,00 \\
\hline
\end{tabular}

Sementara itu, hasil observasi keaktifan siswa dapat dilihat pada Tabel 5. Dari hasil observasi terhadap keaktifan siswa di empat kelompok belajar, masing-masing kelompok mengerjakan tugas sesuai dengan tugas yang diberikan guru. 19 siswa aktif dan ada 11 siswa lainnya tidak memunculkan keaktifan. Secara rata-rata setiap kelompok sudah terlihat aktif namun hal ini belum mencapai kriteria keberhasilan penelitian, sehingga akan dilanjutkan pelaksanaan pembelajaran ke siklus 2 .

Tabel 5 Data hasil observasi keaktifan siswa

\begin{tabular}{lrr}
\hline Keaktifan Siswa & Jumlah Siswa & \multicolumn{1}{c}{$\%$} \\
\hline Aktif & 19 & 63,33 \\
Tidak Aktif & 11 & 36,67 \\
Jumlah & 30 & 100,00 \\
\hline
\end{tabular}

\section{Deskripsi Pembelajaran Siklus 2}

Pembelajaran siklus 2 dilakukan dengan terlebih dahulu menganalisis kelemahan dan kelebihan pada perencanaan siklus 1 . Rumusan perencanaan sebagian besar relatif sama dengan siklus 1 , hanya ada perbaikan terhadap pengajaran yang dilakukan peneliti yaitu peneliti lebih membimbing dan mengarahkan setiap kelompok belajar untuk lebih aktif lagi dalam mengikuti pembelajaran dengan tujuan hasil belajar yang didapatkan akan lebih optimal.

Refleksi pada siklus 2 tidaklah terlalu mendasar, karena sebagian besar tindakan perbaikan telah dianggap optimal dan berhasil. Adapun data hasil deskripsi 
penelitian pada siklus 2 disajikan pada Tabel 6.

Tabel 6 Ketuntasan hasil belajar siklus 2

\begin{tabular}{lrr}
\hline Ketuntasan & Jumlah Siswa & \multicolumn{1}{c}{$\%$} \\
\hline Tuntas & 28 & 93,33 \\
Belum Tuntas & 2 & 6,67 \\
Jumlah & 30 & 100,00 \\
\hline
\end{tabular}

Tabel 6 terlihat bahwa dari 30 siswa terdapat 28 siswa (93,33\%) yang sudah mencapai Kriteria Ketuntasan Minimal (KKM) dalam belajar atau mencapai nilai KKM 70, sedangkan siswa yang memperoleh nilai di bawah KKM sebanyak 2 siswa $(6,67 \%)$. Sementaa itu, data hasil observasi keaktifan siswa dapat dilihat pada Tabel 7.

Tabel 7 Data hasil observasi keaktifan siswa

\begin{tabular}{lrr}
\hline Keaktifan Siswa & Jumlah Siswa & \multicolumn{1}{c}{$\%$} \\
\hline Aktif & 26 & 86,67 \\
Tidak Aktif & 4 & 13,33 \\
Jumlah & 30 & 100,00 \\
\hline
\end{tabular}

Berdasarkan hasil observasi terhadap keaktifan belajar siswa (Tabel 7) diperoleh hasil bahwa siswa yang aktif sebanyak 26 siswa dari 30 siswa $(86,67 \%)$ dan yang kurang aktif 4 siswa dari 30 siswa $(13,33 \%)$, artinya dorongan dari siswa sendiri semakin baik sesuai dengan harapan untuk berprestasi dalam belajar.

\section{Pembahasan}

\section{Hasil Penelitian Siklus 1}

Ketika dilaksanakan tes awal dengan lima butir soal pada materi operasi hitung campuran (perkalian dan pembagian), hanya 21 siswa dari 30 siswa yang mencapai $\mathrm{KKM}=70$ atau ketuntasan belajar hanya $70 \%$ dari indikator keberhasilan penelitian sebesar $80 \%$. KKM = 70 adalah ketentuan dari sekolah melalui mekanisme gugus sekolah, sedangkan indikator keberhasilan minimal 80\% didasarkan pada ketentuan dalam KTSP.

Setiap siklus memiliki 2 aspek yang dibahas sesuai tujuan penelitian tindakan kelas dan permasalahan yang terkandung dalam judul penelitian, yaitu sebagai berikut.

a. Keaktifan Belajar Siswa

Keaktifan belajar siswa dapat diamati langsung dengan menggunakan lembar observasi, dari 30 siswa yang hadir diperoleh data siswa yang aktif sebesar $63,33 \%$.

b. Hasil belajar siswa

Keadaan awal hasil belajar siswa kelas IV SDN Cibunian 01 pada materi ajar matematika operasi hitung campuran (perkalian dan pembagian) di kelas IV SDN Cibunian 01 tergolong rendah dengan nilai rata-rata 69,88 dan ketuntasan belajar $40 \%$ yang di atas KKM, 33,33\% di bawah KKM, dan 26,67\% sama dengan KKM.

Hasil belajar ditentukan oleh gabungan antara kemampuan dasar dan kesungguhan dalam belajar. Kesungguhan ditentukan oleh keaktifan siswa oleh karena itu, sangat penting menumbuhkan keaktifan belajar untuk mencapai hasil belajar. Pada siswa di kelas IV SDN Cibunian 01, dalam proses dan penilaian hasil belajar dilakukan dengan ranah kognitif dan afektif, yaitu ranah dari tiap-tiap siswa yang bersifat relatif stabil dan menjadi kebiasaan individu-individu tersebut dalam hal menerima, mengingat, berfikir, serta menyelesaikan suatu masalah.

Dengan memperhatikan kondisi awal faktor-faktor yang mempengaruhi hasil belajar, dilakukan suatu pendekatan pembelajaran terbimbing melalui metode picture and picture pada operasi hitung 
campuran (perkalian dan pembagian), sehingga diperoleh ketuntasan hasil belajar yang diperoleh pada akhir siklus 1 sebesar $86,67 \%$ dan sebenarnya nilai tersebut sudah mencapai indikator keberhasilan minimal $80 \%$.

Namun, masih ada beberapa siswa yang nilainya di bawah KKM, maka peneliti kembali melanjutkan penelitian ke siklus selanjutnya yaitu siklus 2 untuk memaksimalkan hasil belajar siswa dan keaktifan belajar siswa dalam proses pembelajaran.

\section{Hasil Penelitian Siklus 2}

a. Keaktifan praktik pembelajaran

Pencapaian keaktifan belajar siswa di siklus 2 sebesar 86,67\% lebih besar dari siklus 1 sebesar 63,33\%. Perbaikan atau peningkatan ini menunjukan bahwa perbaikan tampilan peneliti dan sikap siswa semakin berdampak positif terhadap keaktifan belajar. Peningkatan keaktifan belajar siswa ini banyak dipengaruhi oleh sikap berani siswa, baik dalam diskusi kelompok maupun individu, serta siswa semakin aktif melakukan pembelajaran di bawah bimbingan peneliti.

b. Hasil belajar

Perubahan aktivitas yang ditunjukan pada siklus 2 ini, menunjukan bahwa seluruh siswa mengikuti proses belajar mengajar dengan baik. Seiring meningkatkan keaktifan belajar siswa pada siklus 2, maka berdampak pula pada meningkatnya hasil belajar siswa yang ditunjukkan dengan peningkatan hasil belajar siswa yang mencapai KKM. Terbukti dari 30 siswa terdapat peningkatan sebanyak 28 siswa atau sebesar 93,33\% telah mencapai KKM. Hal ini menunjukan bahwa penelitian yang dilakukan peneliti dapat dikatakan sudah sesuai dengan tujuan penelitian atau dengan kata lainnya berhasil.

Berdasarkan analisis terhadap hasil penelitian di tiap siklus diketahui bahwa pada aspek pendekatan kognitif penilaian hasil belajar diperoleh hasil di siklus 1 sebesar $86,67 \%$ dan siklus 2 sebesar 93,33\%. Sedangkan analisis terhadap hasil observasi keaktifan belajar siswa atau pada aspek afektif diperoleh pada siklus 1 sebesar $63,33 \%$ dan siklus 2 sebesar $86,67 \%$.

Hasil analisis tersebut menunjukkan bahwa penerapan metode picture and picture dapat dikatakan berhasil dalam meningkatkan hasil belajar dan keaktifan belajar siswa. Hal ini dibuktikan dengan adanya 28 siswa memperoleh nilai hasil belajar yang baik, 26 siswa secara aktif mengikuti pembelajaran dan ditemukan hanya 2 orang siswa berkompetensi lemah, serta hanya 4 siswa yang ditemukan kurang aktif dalam pembelajaran.

Berdasarkan tabel hasil belajar dan keaktifan belajar siswa, dapat dijelaskan bahwa kenaikan hasil kedua aspek yaitu keaktifan belajar siswa dan hasil belajar siswa jika dilihat dari nilai rata-rata dalam setiap indikator dalam siklus 1 dan 2 sangat berkualitas/baik, dengan ketentuan indikator maupun KD dapat dinyatakan melebihi $\mathrm{KKM}=70$ serta indikator keberhasilan penelitian minimal $80 \%$ juga sudah tercapai.

\section{KESIMPULAN DAN IMPLIKASI}

\section{Kesimpulan}

Berdasarkan pembahasan hasil penelitian dapat disimpulkan bahwa:

1) penerapan metode picture and picture dalam pembelajaran operasi hitung 
campuran (perkalian dan pembagian) dapat meningkatkan hasil belajar siswa pada mata pelajaran matematika kelas IV SDN Cibunian 01 Kecamatan Pamijahan Kabupaten Bogor semester 1 tahun pelajaran 2016/2017. Hal ini diketahui dari analisis terhadap aspek kognitif pada penilaian hasil belajar siklus 1 diperoleh hasil sebesar 86,67\% dan pada siklus 2 sebesar 93,33\%;

2) melalui metode picture and picture dalam pembelajaran operasi hitung campuran (perkalian dan pembagian) di kelas IV SDN Cibunian 01 Kecamatan Pamijahan Kabupaten Bogor semester 1 tahun pelajaran 2016/2017, dengan cara menggunakan media gambar, charta atau kartu huruf yang ditempeltempelkan secara berkelompok dinyatakan berhasil dengan nilai baik karena interval nilai dengan makna baik antara (60-80);

3) melalui metode picture and picture dalam pembelajaran operasi hitung campuran (perkalian dan pembagian) di kelas IV SDN Cibunian 01 Kecamatan Pamijahan Kabupaten Bogor semester 1 tahun pelajaran 2016/2017, dengan cara menggunakan media gambar, charta atau kartu huruf yang ditempeltempelkan secara berkelompok dapat menciptakan keaktifan siswa seperti siswa berani, aktif, bertanya kepada guru jika ada yang kurang dipahami, dan

tidak segan maju ke depan kelas untuk mengerjakan tugas yang telah diberikan. Oleh karena itu, dapat dikatakan bahwa penerapan metode picture and picture membuat siswa lebih aktif, antusias, dan merasa senang dalam mengikuti pembelajaran matematika di sekolah.
Dengan demikian, dapat dikatakan bahwa penggunaan metode picture and picture dapat meningkatkan hasil belajar dan keaktifan belajar siswa kelas IV SDN Cibunian 01 Kecamatan Pamijahan Kabupaten Bogor pada semester 1 tahun ajaran 2016/2017.

\section{Implikasi}

Implikasi dari hasil penelitian ini yakni pembelajaran dengan metode picture and picture dapat dilaksanakan dengan baik apabila guru merencanakan pembelajaran ini dengan optimal dan pada prosesnya dilakukan pengamatan dan pengarahan yang seimbang sehingga metode ini dapat berhasil mencapai tujuan pembelajaran.

Pada proses pembelajaran menggunakan media gambar peserta didik dapat terlibat langsung dan sangat aktif sehingga tak jarang ada pertengkaran atau perselisihan. Sehingga guru harus pandai mengatur dan mengarahkan agar tujuan pembelajaran tetap tercapai yaitu dengan membentuk kelompok-kelompok yang dibekali masingmasing satu karton bergambar mengenai teknik membilang perkalian dan pembagian yang menyenangkan.

Sebaiknya siswa mempunyai sikap yang berani dalam proses pembelajaran, lebih aktif, dan lebih termotivasi belajar di semua mata pelajaran seperti pada pembelajaran dengan metode picture and picture yang dilakukan oleh peneliti, karena hasilnya sangat baik dan positif.

\section{DAFTAR PUSTAKA}

Baharuddin dan Wahyuni EN. 2007. Teori belajar dan pembelajaran. Ar-Ruzz Media, Depok.

Esti. 2015. Meningkatkan kemampuan operasi hitung siswa SD. Skripsi. FKIP UNY, Yogyakarta. 
Purwanto. 2011. Evaluasi hasil belajar. Susanto A. 2013. Teori belajar dan Pustaka Pelajar, Yogyakarta. pembelajaran. Kencana, Jakarta.

Sunal CS dan M Haas. 1993. Social student Tampubolon S. 2014. Penelitian tindakan and the elementary/middle school student. kelas. Erlangga, Jakarta. Harcourt Brace Jovanovich College Publishers. Fort Worth. 